\title{
FROM SIMPLE TOURISM TO SMART TOURISM: THE BET FOR THE DEVELOPMENT OF A RESPONSIBLE AND SUSTAINABLE TOURISM. CASES IN THE ZIGUINCHOR REGION (SENEGAL)
}

\author{
Seedou Mukthar SONKO * \\ Assane Seck University of Ziguinchor, Training and Research Unity of Economic and Social Sciences, \\ Department of Tourism, Senegal, e-mail: sm.sonko@univ-zig.sn
}

Anca Luminita DEAC

University of Oradea, Department of Geography Tourism and Territorial Planning, Universitatii Street no 1, 410087, Oradea, Romania, e-mail: anca_deac@yahoo.com

\begin{abstract}
Citation: Sonko, S.M., \& Deac, A.L. (2020). From Simple Tourism to Smart Tourism: The Bet for the Development of a Responsible and Sustainable Tourism. Cases in the Ziguinchor Region (Senegal). Analele Universității din Oradea, Seria Geografie, 30(1), 10-19. https://doi.org/10.30892/auog.301102-838
\end{abstract}

\begin{abstract}
Tourism has become an essential activity for the economies of the countries, and it is an activity that has a long way to go. Thus, this activity, previously uncontrolled in the face of what is nowadays called responsible tourism, is nowadays a sector followed with rules and standards to be respected. Tourism activity has gone from what was mass tourism, to a new form of tourism which is required in relation to the management of both tourist flows and also to the protection of the environment. We are now talking about sustainable tourism or responsible tourism. So we were thinking here about the evolution of tourism; from simple displacement to rational and responsible displacement.
\end{abstract}

Key words: tourism, displacement, environment, sustainable, economy

$* \quad * \quad * \quad * \quad * \quad *$

\section{INTRODUCTION}

Developing countries have been welcoming a significant number of visitors for some time. The result of this development of tourist arrivals is not only in terms of job creation, but also in terms of foreign exchange injected into the places visited. However, we must not lose sight of the fact that the development of this activity has negative consequences both in environmental and societal terms. It is therefore vital to rethink this activity in order to benefit from it and reduce its negative effects. "The 2018 World Tourism Organization, Tourism Highlights show that international tourist arrivals totaled 1,326 million in 2017, some 86 million more than the previous year, reaching a new record (WTO, 2018). The sector has experienced an uninterrupted growth in arrivals for eight consecutive years.

\footnotetext{
* Corresponding Author
} 
The increase in 2017 was the strongest since 2010, with the European and African regions topping the picture, with $8 \%$ and $9 \%$, respectively, increasing arrivals" (WTO, 2018). The WTO predicts an increase in the arrival of international tourists to reach 1.6 billion by 2020 . These figures show that the desire to travel and discover is becoming more and more important in the world, and that people want to go and see what is happening on the other side of the usual environment. As an uncontrolled turn, tourism, too, if poorly managed, often leads to upheaval in visiting communities. And very often, the countries visited are poor countries where the cost of living is much lower than that of the countries of origin of the visitors, with a very fragile environment. Tourism means the displacement of people outside their usual environment for a consecutive period of no more than one year. At first, this activity was reserved for a bourgeois class who did what they called "Grand Tour". Today we note a democratization of this activity. That is, everyone can go sightseeing when you have free time. Tourism has become an industry whose management requires knowledge and mastery of many of its workings.

The Ziguinchor region in the south of Senegal is known for its greenery, its lush vegetation and its diversity of fauna. The latter is an undeniable asset that attracts many visitors to the region. Thus; it is high time, with the rapid development of tourism, to think about the rational management of the natural heritage within the framework of a regional or local tourism policy.

The main idea of this activity, which concerns the players in the sector, is to fill up in their accommodation or catering establishments.

This is only the positive side of tourism. Yet culture and the environment are the biggest losers in all of this. So to protect this natural and cultural heritage, we are now talking about sustainable tourism, responsible tourism. In this type of tourism the environment is at the heart of all its promotion.

It should not be forgotten that forests must be destroyed at times for the sole purpose of building hotels or certain tourist establishments. The arrival of visitors can also lead to a cultural conflict that sometimes leads to a total rejection of this new activity. The local architect may also be disrespected, which may change the postcard or the originality of the locality. We can name it as we like, but the need to take all the problems of management and protection of the environment into account is now an obligation for all hotel developers and even all the players in tourism.

What is to be banned is to believe that environmental protection is the responsibility of the state, not far from it everyone must feel concerned about this environmental degradation. In tourism, the players focus much more on the policies of promoting destinations while neglecting the protection side, both of the environment and of the heritage. And yet, to put in place a good policy of environmental management, would be an asset both in terms of marketing of the destination and also in terms of finance. So we're here in an environmental or ecological management system: eco-management.

The environmental or (eco-management) management "It is not enough to allow nature and the market economy to do so by suggesting that an economic life can be born and developed by the sole attraction of the territories privileged by nature, history or geography" (Deprez, 2006, p. 45) of a tourist equipment is a condensed version of two seemingly contradictory principles: save natural resources and maximize the return on exploitation.

However, it would be necessary to make it compulsory for all players in the hotel-tourism and catering industry to respect the requirements of the environment and that these requirements be considered as a standard. So we talk about sustainable development. Sustainable development is therefore a long-term management policy that advocates other ways of producing and consuming. While recognizing that some major hotel groups such as Accor have established a hotel environment charter. This implies an awareness of integrating the environment into their policy of opening hotels. This concept is based on a logic modeled on the development of science.

Analyses and synthesis of research papers and direct interviews following with some of the tourism actors from Ziguinchor region level. 


\section{TOURISM AS A GROWING ACTIVITY}

Tourism activity is increasing and international arrivals are increasing. For those hosting companies that are directly linked to this activity, there is a need or a duty to respect the environment in which tourism takes place (Herman et al., 2016b, 2017, 2018; Ilie et al., 2017; Lincu et al, 2018). Even customers have become aware of environmental protection. They are now and increasingly opting for a clean destination. This would mean that the concept of sustainable tourism is no longer a vain word, but a reality that could be of interest to business marketing managers. The hotel, tourism and catering sector is one of the leading providers of jobs. This means that a lot of people work there. For example, an institution that is intended to be "green" must also put in place a new policy within the company and with its shareholders to strengthen its status as an "eco-hotel". "This news gives in the apprehension of tourism as a factor of development is emerging and the whole of this talk applies to include tourism in a true process of sustainable development" (Laurent, 2009, p. 43).

While the relationship between man and his environment is a perfect illustration of his historical past, it is undeniable that the advent of certain activities such as tourism or the technological revolution has had many positive and negative consequences. In fact, the problems caused by the use of natural spaces for the construction of hotels, for example, have increased enormously in recent years. For example, consider a tourist area such as Cape Skiring in the Ziguinchor region of Senegal "The tourist economy, far from being a danger to the environment, must be one of the first national, regional, communal and inter-communal expressions of environmental policy" (Deprez, 2006, p. 84), where all the land is sold to build accommodation establishments. The anarchic construction that is noted is as worrying as the degradation of the environment. The local population continues to grow as the living space shrinks. What should be done? The situation is becoming increasingly unlivable. If you want to develop a tourist activity at all costs, you risk killing it. Because, you have to know that tourism itself contains what can make it disappear. Very often rural populations suffer the most from this environmental degradation. Developing countries are not left behind in the development of tourism.

Tourism has thus become a global phenomenon that brings all the countries of the world together. Therefore, it is necessary, if not essential, to establish agreements between the countries of the south and those of the north in order to learn from the positive experiences of the latter.

According to Alain Laurent (2009), "Decentralized cooperation is therefore playing an important role and will play an increasingly important role in international relations. Indeed, it has many advantages: it is built over time, from territories of proximity and individual will, and shows institutional and democratic legitimacy, territorial roots, sustainability; it remains controllable and measurable in actions; it allows the citizens of different countries to come together. It is simply human-sized" (Laurent, 2009, p. 386).

We may sometimes be tempted to ask ourselves the question of the development of tourism in conjunction with the protection of the environment or heritage in general. So trying to give an answer to this problem could lead us to make a small retrospective of the birth of tourism. One thing is for sure, that the heritage was there long before the tourist activity. Heritage is for tourism what gasoline is for the car. He's used as a fuel to move forward. That is why Olivier Lazzarotti said: "Tourism and heritage are currently engaged in an uninterrupted and intertwined dialog. Sometimes in agreement, sometimes in disagreement, and most often both“" (Lazzarotti, 2011, p. 73).

Education for sustainable development or sustainable tourism is required today (Ruhanen et al., 2015; Herman et al., 2016b; Ilieș et al., 2017a; Tătar et al., 2018) at the level of all major hotel groups. It is based on the ownership of the concept of eco-management. The customers that these companies must target will have to prove that they are part of this concept. So a new type of tourism can be created. This involves the tourist who first thinks of the environment and only after that thinks about his stay. "Tourism became mirage. Nothing could stop him, no one dared to raise any doubt. He had free ground. It represented progress, the future, the end of poverty" (Laurent, 2009, p. 17). 
The number of tourists who are constantly increasing at the international level and the impact on the visited areas deserve to be well assessed. Indeed, globalization, which has reached its highest peak, the possession of the right information, also gives us control. The more tourists know the area through the media, the better they will get ready before arriving at the destination to visit. The quest for discovery is also a quest for knowledge. Tourism can therefore contribute to the protection of the environment and more generally to heritage.

Table 1. Effects of tourism on the environment

(Data source: Saida Merasli 2012)

\begin{tabular}{|l|l|}
\hline Effects & Examples \\
\hline Air pollution & Transport sector, increased electricity consumption \\
\hline Water pollution & $\begin{array}{l}\text { Water pollution Wastewater from hotels and boats, oil spills from motor } \\
\text { boats. }\end{array}$ \\
\hline Solid waste & $\begin{array}{l}\text { Solid Waste Discarded by tourists and tourism industry workers, and garbage } \\
\text { they produce }\end{array}$ \\
\hline $\begin{array}{l}\text { Loss of natural spaces } \\
\text { and biodiversity }\end{array}$ & $\begin{array}{l}\text { Loss of natural spaces and biodiversity Building of buildings (installation and } \\
\text { accommodation for tourists), infrastructure (roads, trails, ) Tourism behavior }\end{array}$ \\
\hline Noise & Noise Increased traffic, airplanes, recreational vehicles, entertainment facility \\
\hline
\end{tabular}

Today, sustainable development is seen as a value for the quality of business or hotel. For this purpose, a number of lodging establishments are given an environmental label.

"Now, the need for ethics, fairness and safeguarding of resources is also evident in the company. This means an affirmation of a social role for the company ..." (Merasli, 2012, p. 52).

Tourism, which is known as a factor of economic development of countries, is based on these assets of the territories to develop its activity. This is a social fact and links culture and economics. This characteristic of tourism joins that of sustainable development, which also encompasses the environmental, economic and social aspects. To meet the new requirements of the competition market, tourist destinations must take all these criteria into account.

For, it is often said that managing is predicting; so the sense of anticipation and forecasting is paramount in a sector as competitive as tourism.

The motivations and tastes of the customers change, so this evolution must be followed in order to bring to the market a supply adapted to the demand. Even being far from the territory to visit; tourism has a major influence on the choice of offers to be placed on the market. Tourism now requires a more qualitative and environmentally friendly offer (Gozner et al., 2017).

In all tourism wants another new mode of tourism different from the years of mass tourism.

Mass tourism was in some ways a tourist activity where the number of visitors was not controlled or channeled well. Visitors travel without the application of the load capacity of the sites visited. This causes huge damage at the end of the visitor's stay. In the implementation of sustainable tourism indicators, strict application of load capacity standards is mandatory. The maximum number of visitors a site can receive at the same time is the capacity of the load. The practice of tourism cannot be designed without taking into account the particularities or specificities of the territory concerned. The term "sustainable" has become an essential term in destination sales. This could explain the exploitation of local resources without any consequences in the future. The development of sustainable tourism also requires that the benefits of this activity be shared equally. Tourism that does not contribute to local development is not sustainable tourism. In this sense, Bernard Schéou states that: "Tourism is undoubtedly an effective means of economic enrichment for its beneficiaries, but having financial means is far from systematically driving development, it is only one of the many conditions necessary to achieve development" (Schéou, 2009, p. 138).

States should not only look at the interests of their offers, but also at the interests of the people. For developing tourism without taking into account the interests of the local population is 
bound to fail. And according to Schéou (2009), "Governments often fish through their desire to increase tourism revenues by maximizing the number of visitors rather than engaging in the search for a form of tourism that would benefit the population" (Schéou.2009, p. 140).

This policy would be totally contradictory to a sustainable development policy. This environmental policy has had enormous constraints, given the disparity in awareness among some hoteliers regarding the importance of being "green". The current situation in the Cap Skiring area is an example of this. The anarchic construction of tourist accommodation facilities is at the height of its disasters. Access to the beach has become virtually impossible for the local population, and yet it is exactly what has welcomed these investors who have become "persona non grata".

It is imperative that the State take measures in this regard to avoid cocoa in the years to come. However, in order to reach the entire territory in relation to this policy, it would be necessary to implement it at the local level, because the local dimension can be an example of success that could be expanded at the national territorial level.

"With decentralization, the initiative is left to local, public and private actors in a much wider way, and it becomes necessary to put in place posteriori mechanisms to monitor compliance with the rules defined at national level" (Barraqué and Theys, 1998, 11).

The hotel and tourism industry in some of the peripheral areas, which have had to suffer a massive exodus of its population, cannot establish a clear policy of its needs. These areas do not have a strategy to defend their environment, they simply consume everything that investors or large hotel groups offer them. We note that most of the projects that are located in environmentally sensitive areas are projects by sector of activity.

In a logical sequence of a project package, it is first of all the responsibility of the project developer to carry out a field study, to inform the local populations of the interest of the project. Non-involvement of local people in a project may lead to its failure. So the population needs to participate in the discussion in order to put in place a plan that could help to keep the population at the local level, thus curtailing the rural exodus. For example, a sustainable tourism project that respects the environment (Ilies et al, 2017a; Ilies et al, 2017b).

However, the implementation of such a project must respect a specific approach strictly related to the equipment to be used. It would therefore be necessary to set up a program that informs on social, economic and cultural issues in order to integrate tourism into local life.

\section{ENVIRONMENTAL CONSIDERATIONS IN TOURISM PROMOTION}

For tourists who arrive in an environmentally sensitive area, standards of compliance with the minimum level of attendance are put in place so as not to cause damage that can sometimes be irreversible. This is what has been called "load capacity" at the top. Of course the load capacity differs from one area to another and according to the specific characteristics of the area. "Tourism is transforming the place. This may explain the frequency with which tourism is blamed for all the evils, but, also and paradoxically, it is summoned to solve all the evils and is often seen as the last bulwark against the inevitable decline of some agricultural and industrialized places in crisis" (Violier, 2008, p. 43).

This means, therefore, that the load capacity, also known as hosting capacity, is not limited only to a fixed number, but rather to well-defined patterns of the distribution of tourist arrivals on a site. When it comes to environmental protection, this is not only limited to nature, not far from it, making tourism in other ways means that both visitors and business owners have to manage rationally all the waste, some of which were mentioned in table 1 . In underdeveloped countries, water is the subject of many tensions between populations. There is indeed a lack of water that it would be foolish to tolerate its waste by certain hotel groups. It is impossible to imagine that in a hotel, the owner uses as many cubic meters of water to water his golf course, while a few kilometers from the establishment people die of thirst, or they barely have good quality water. "In any case, it is common for many powerful interest groups like many governments to consider 
improving the performance of the water industry through reorganizations or changing its position within or outside the public sphere" (Barraqué and Theys, 1998, p. 91).

Tourism cannot be done without taking the environment into account, it would be part of the sudden death of this activity. We talk about green tourism, eco-tourism, all to show the attachment of tourism to nature. Marie-Pierre Hage said, "The freedom of the individual is associated with the love of nature, and to be able to reconcile nature and freedom, one must escape society" (Hage, 2015, p. 35).

In other words, to claim to be an "Ecolo" hotel, it is necessary to integrate environmental management into its policies. If hotel developers and all tourism players gave some consideration to nature and the environment in general, human life might be saved. In the fight for the protection of the environment, governments should put in place strict rules to be followed by any promoter of a tourist project and, above all, wishing to establish a place in rural areas, for pollution has become the worst enemy of man today. Large cities have become traveling tombs, a purely ecological problem that traces the consequences of poor environmental management and overexploitation of natural resources. So, to address this growing scourge, we are talking about sustainable development, sustainable tourism or responsible tourism. In this tourism, the aim is to set up classification criteria in order to provide institutions with a framework to follow in order to become green again. Both government and private authorities are concerned with the global threat of "global warming" and tourism, which is a social fact, affects the environment. "The debate on environmental issues calls for our attention to the extent that it is an opportunity for questioning; of a philosophical scope, economic, social and political institutions of the contemporary world" (Vaillancourt, 1992, p. 27).

Developed countries must now clearly identify their donations to underdeveloped countries. The intervention of the European powers in the underdeveloped countries must be controlled because, in some cases, obsolete products arrive without any control at the level of the underdeveloped countries. What is called "aid to underdeveloped countries" is much more like "aid to pollution." For a society that advocates tourism development, it is important that political choices or decisions that affect the public or public good be explained and that the public be able to express their views on those choices. Because the consequences of a poor choice can be felt at the population level. To get the population's perspective, you just have to take a survey and look at your questionnaire before you get the right conclusion. "The economic analysis on which concrete solutions to environmental problems are based takes into account first and foremost the technological factors which are not easy to analyze" (Vaillancourt, 1992, p. 73).

Indeed, economic issues will always be the focus of discussion when talking about the environment. The biggest problem we face is that of making a proper assessment of the level of environmental degradation. While it is known that methods exist and cost each environmental assessment, it is also necessary to agree that the environment has no exchange value. He has no price. Therefore, the realization of certain political decisions on the protection of nature must necessarily be based on the basis, i.e. at the local level. Particular consideration should be given to how this can be achieved in order to make concerted decisions on a resource at risk.

Tourism is an activity that makes people move outside their environment, so the territory is inseparable from this activity. "Modern tourism, which seeks, outside its home and workplace, a framework of escape that may attract it, must be considered increasingly likely to seek the preservation of all pollution, where it hopes to find a change of scenery and enjoy rest and freedom" (Deprez, 2006, p. 88).

The territory is both the starting point and the center of the tourist activity. The place and role of the natural space as a whole, both ecological and human, are at the heart of the relationship with the development of tourism. Tourism cannot be developed without a territorial base.

The promotion of a destination is done within the geographical boundaries of the country or region. Each territory has its own particularity, its assets. This represents its apparent part or even the first tourist attraction of the area. This is like confirming that landscape protection is the key to success of any tourism development. Because without the landscape, or a healthy 
environment point of tourism. "In most tourist communications, whether commercial or promotional, landscapes occupy a privileged place... Today, even landscapes as far away as those of the Arctic or Antarctica have become advertising images for touristic tours or hikes..." (Lozato-Giotart et al., 2012, p. 29).

From the first stage of the design of a tourist project, a feasibility study is necessary in order to be able to make an assessment of all the attractive potential of the area as well as the possible limits of occupancy at the level of the territory. This means that an analysis of the possibility of setting tourism or the "tourist" of the territory will be carried out due to its assets and attractions. However, it must be recognized that an assessment of the tourist potential of all places where you want to invest is not always an easy thing. In fact, very subjective judgments and quick reviews were given against certain sites. Thus, it was sufficient for a destination to have some assets even if they are not highlighted, such as a beach, sun, a landscape, and to embark on a tourist development. To say that a destination has a rich heritage means somewhere that this heritage is well protected. The destination may be full of heritage or attractions and not a popular destination. For a destination to be known and appreciated, it is necessary to highlight its heritage and then put it on the tourist market. Simply put, a product that does not enter the market is a nonexistent product. We are talking about heritage, but what we must remember is heritage is not only what is built. Indeed, heritage can have an intangible dimension that has a direct connection with the customs and customs of local populations. Nowadays, it is not possible to get into this activity without a preliminary field study, of putting into tourism the existing potentialities, in order to pretend to make sustainable tourism. The introduction of tourism also means the establishment of sufficient accommodation infrastructure that meets the standards of quality. Without this, the destination can have all the tourist assets possible but will never be a popular destination.

The bed capacity is an indispensable component in the development of tourism. Since almost all of them are dependent on European countries, the developing countries are building their tourist policy in line with the "foreign" tourist. Indeed, if we take the example of Senegal in general and the Ziguinchor region in particular, tourism is much more dependent on international tourists, mostly French tourists than national tourists. Therefore, by calculating the departure frequency and arrival frequency, it is concluded that Senegal is a receiving country. It receives more tourists than it emits. Tourism seems to be a cultural factor, even if we note a globalization of this activity (Herman, 2016a).

At the accommodation level, some employees are able to distinguish between a French tourist and an English tourist. "Culture, in fact linked to the concept of travel and hospitality, plays a fundamental role in determining an individual's needs and partly shapes his behavior" (LozatoGiotart et al., 2012, p. 47).

In tourism, the management of the tourism supply-demand confrontation is of paramount importance. The intersection of the two concepts demonstrates the need to place on the market (supply) a product that meets the expectations of consumers (demand). The OMT in its publications projects an increase in the influx of international tourists, which could reach 1.6 billion by 2020. This increase in the number of arrivals must be accompanied by an increase in air traffic. This means that in order to make more aircraft available to travelers, especially long-haul aircraft, a reflection on the emission of gas by aircraft is necessary in order to minimize pollution. The development of tourism cannot be achieved without the joint participation of public and private actors. Tourism is a factor in democracy.

Despite geopolitical tension, crises and terrorist attacks, tourism seems to be one of the sectors that best resists these scourges. As the world struggles with global warming, the danger of the disappearance of certain landscapes, it would be necessary to think about a new type of tourism. What type of tourism can we think about without nature? This question may seem trivial to us, but it has several meanings. In some places where tourism is developed, $\mathrm{CO}^{2}$ emissions from travel are very often noted, causing pollution. In the face of this environmental disaster and the lack of ideas from our politicians for the protection of nature, in the face of the worries that the 
world will one day fall on our heads, the new type of tourism must try to find answers to all these questions (how could we travel, visit or even live without a healthy environment). Despite its significant financial and economic impact, tourism also has negative environmental impacts on the areas visited (Ilies et al., 2017c; Tătar et al., 2017, Wendt et al., 2019).

So governments and also tourism players have understood the imbalances that this activity can cause if it is mismanaged. "Environmental impacts are a question, social and societal responsibility is called upon to take these phenomena into account. We are back in the so-called co-responsible years where all actors (citizens, professionals, communities) must integrate the new environmental variables for new ways. To practice tourism otherwise will become a must" (Babou and Callot, 2012, p. 12).

We pointed out at the outset that there is a notable difference between making sustainable development of tourism and focusing on the sustainable development of a destination or territory as a whole. It is also about the contribution of tourism to the sustainable local development of a territory. Tourism planning is much more oriented nowadays by the concept of sustainability. This requires a policy of planning the tourist activity oriented towards the protection of the environment and local development. Now and in most countries, the natural environment is at the center of all their policies to promote and develop tourism.

"Based on a democratic decision-making process, tourism planning also raises the question of the authority of the various stakeholders in the tourism phenomenon. Planning appears to be constrained by various economic and political pressures that can deter it from its priorities (environmental sustainability versus economic challenges in terms of jobs, for example)" (Cooper and Hall, 2011, p. 122).

The cross-cutting nature of the tourist activity, which involves several other sectors, can be seen from all the elucidations at the top. Indeed, tourism is inseparable from geography or sociology. There's more and more talk about the geography of tourism, or the sociology of tourism. However, some researchers who advocate a "tourism science" think that tourism activity is much more oriented towards human or social science. This could be positive, because what makes tourist activity unique are individuals moving to an unusual place. So tourism is above all a social fact, however, the word social tourism, although it has resisted time, has not imposed itself over time. No tourist claims to be social.

\section{CONCLUSIONS}

Tourism is undeniably an activity that affects the whole world. Indeed, it is almost impossible to see a corner of the planet that has never been visited by a tourist. By a corner of the planet, we understand a destination or a country. The travel of the tourist is based on his motivation, it is clear that every tourist has his preferences or his purpose of the trip. Tourism is a form of development based on both cultural and environmental resources. It is also another way for individuals and societies in general to better understand and master their environment and past.

The analysis of the phenomenon at various levels has revealed some problems or contradictions in its way of functioning.

It is clear that today tourism is considered to be a well-organized activity that works in line with the evolution of the technological world. Some believe that culture is the basis for any development of tourism, but we can say that the environment is the most important factor in the development of tourism. The fact that the environment has a role to play in economic development is obvious, but its contribution is indirectly through tourism and human development. In this article, we wanted to speak out against the way in which certain tourist companies or destinations claim to decide in a non-rigorous way, another way of promoting their destination or business.

The whole world is now talking about sustainability. All the actions that must be taken today must not jeopardize the future of future generations. It is in this sense that we have been able to make some arguments, because we are convinced that this activity of tourism can claim a better classification among activities that act in sustainability, in general in the protection of the 
environment and heritage in general. Whether tourism occupies the place that the "Tourismologists" will give it or eclipse itself in a much more undifferentiated subset. In order to be able to do tourism in a different way, it was necessary to raise awareness among the authorities of the importance of implementing a policy of "labeling" companies that act in a sustainable way. The destinations as well as the tourist players are not left out. Overall, involving the tourist in the study of the tourist phenomenon is a laudable idea. The tourist who can be called "modern" has to be an environmentally friendly tourist. It should be noted that tourism, which has become an international phenomenon, the protection and management of the natural heritage of the destinations must be considered as a fight of international relations.

\section{Aknowlegments}

The authors wish to thank to anonymous reviewer for their thoughtful suggestions and comments. Many thanks to Mr. Gora Lo, Director of the Library of Assane SECK University, for giving me the opportunity to access certain documents.

\section{REFERENCES}

Babou, I., \& Callot, P. (2012). Que serait le tourisme sans pétrole? [What would tourism be like without oil?], L'Harmattan (in French).

Barraqué, B., \& Theys, J. (1998). Les politiques d'environnement, évaluation de la première génération, 1971-1995 [Environmental policies: First Generation Evaluation 1971-1995] (in French).

Bernard, N., Blondy, C., \& Duhamel, P. (2017). Tourisme et périphéries [Tourism and peripheries] (in French).

Choi, H. S. C., \& Sirakaya, E. (2005). Measuring residents' attitude toward sustainable tourism: Development of sustainable tourism attitude scale. Journal of Travel Research, 43(4), 380-394.

Coope, C. \& Hall, C. M., (2011). Tourism today: An international approach. De Boeack.

Deprez , L. (2006). Tourism economy or accessible growth and sustainable development. Publisbook

Dewailly, J. M. (2006). Tourisme et géographie entre pérégrinité et chaos? [Tourism and geography: between Peregrinity and Chaos?], Editions L'Harmattan (in French).

Frochot, I., \& Legohérel, P. (2018). Marketing du tourisme-4e [Tourism marketing: Build an effective strategy], éd. Dunod (in French).

Garrod, B., \& Fyall, A. (1998). Beyond rhetoric of Sustainable Tourism Tourism Management.

Gozner, M., Tătar, C. F., Stupariu, M., \& Măduța, F. M. (2017). Nature, Photography and Tourism in Bihor-Vlădeasa Mountains (Romania). GeoJournal of Tourism and Geosites, 20(2), 210-219.

Hage, M.-P. (2015). Ecological Emergency: Before it's too late. Free and Solidary.

Herman, G. V., Deac, A. L., Ciobotaru, A. M., Andronache, I. C., Loghin, V. \& Ilie, A. M., (2017). The role of tourism in local economy development. Bihor County Case Study. Urbanism Architecture Constructions 8(3): 265-274.

Herman, G. V., Grama, V., \& Stupariu, I. (2016a). The international organisations between globalization and regionalization. Case study: world tourism organization. Revista Română de Geografie Politică, 28(2), 49-59.

Herman, G. V., Ilieș, D. C., Baias, Ș., Măduța, M. F., Ilieș, A., Wendt, J., \& Josan, I. (2016b). The tourist map, scientific tool that supports the exploration of protected areas, Bihor County, Romania. GeoSport for Society, 4(1): 24-32.

Herman, G. V., Ilieș, D. C., Măduța, M. F., Ilieș, A., Gozner, M., Buhaș, R., \& Mihók-Géczi, I. M. T. (2016c). Approaches regarding the importance of Natura 2000 sites' settings pupil's education through geography. Case study: Valea Rose (Red Valley) Natura 2000, Bihor country, Romania. Journal of Geography, Politics and Society, 6(4), 57-62.

Herman, G. V., Peptenatu, D., Grama, V., \& Pintilii, R. D. (2018). Tourism and Local Development. Study Case: Băile Felix-Băile 1 Mai Tourism System, Bihor County, Romania. Analele Universitatii din Oradea, Seria Geografie, 28(1), 131-137.

Ilie A. M., Herman G. V., Ciobotaru A. M., Grecu A., Radu R. A., Visan M. C., \& Giurgia M. (2017), The role of tourism in structural dynamics of the economic profile of Sighisoara city. Urbanism. Arhitectura. Constructii [Urbanism Architecture Constructions], 8(4), 377-386.

Ilieș, D. C., Baias, S., Buhaș, R., Ilieș, A., Herman, G. V., Gaceu, O., ... \& Măduța, F. (2017a). Environmental education in protected areas. Case study from Bihor County, Romania. GeoJournal of Tourism and Geosites, 19(1), 126-132.

Ilieș, D. C., Herman, G., Ilieș, A., Baias, Ș., Dehoorne, O., Buhaș, S. \& Ungureanu, M. (2017b). Tourism and Biodiversity in Natura 2000 Sites. Case Study: Natura 2000 Valea Roșie (Red Valley) Site, Bihor County, Romania. Études caribéennes, (37-38).

Ilieș, D. C., Herman, G., Ilieș, A., Baias, Ș., Dehoorne, O., Buhaș, S., \& Ungureanu, M. (2017c). Tourism and Biodiversity in Natura 2000 Sites. Case Study: Natura 2000 Valea Roșie (Red Valley) Site, Bihor County, Romania. Études caribéennes, (37-38).

Laurent, A. (2009). Responsible tourism, key to sustainable territorial development, Lyon, Social Chronicle (in French). 
Lazzarotti, O. (2011). Patrimoine et tourisme: histoire, lieux, acteurs, enjeux [Heritage and tourism; History, places, actions and issues], Paris, FR: Belin (in French).

Lincu, A., Ilieș, M., Ilieș, D. C., Herman, G. V., Baias, S., Gozner, M., ... \& Mihincău, D. (2018). Conservating the Traditional Cellars of Salacea, Bihor County, Romania. GeoJournal of Tourism and Geosites, 23 (3), 748-758.

Logossah, K. I. N. V. I., \& Salmon, J. M. (2005). Tourisme et Développement durable [Tourism and sustainable development], Publibook (in French).

Lozato-Giotart, J. P., Leroux, E., \& Balfet, M. (2012). Management du tourisme: territoires, offres et stratégies [Tourism Management: Territories, Offers and Strategies], Pearson Education France (in French).

Prades, J. A., Tessier, R., \& Vaillancourt, J. G. (1992). Gestion de l'environnement, éthique et sociétél Environmental Management: Ethics and Society], Les Editions Fides (in French).

Ruhanen, L., Weiler, B., Moyle, B. D., \& McLennan, C. L. J. (2015). Trends and patterns in sustainable tourism research: A 25-year bibliometric analysis. Journal of Sustainable Tourism, 23(4), 517-535.

Schéou, B. (2009). Du tourisme durable au tourisme équitable: quelle éthique pour le tourisme de demain? [Sustainable tourism; what ethics for tomorrow's tourism], De Boeck Supérieur (in French).

Tătar, C. F., Herman, G. V., Dehoorne, O., \& Zarrilli, L. (2017). Ecotourism in the Danube Delta. Analele Universităţii din Oradea, Seria Geografie, 27(1), 122-132.

Tătar, C., F., Herman, G., V., \& Gozner M. (2018). Tourist guides' contribution to sustainability in Romania. GeoJournal of Tourism and Geosites, 21(1), 282-287.

Violier, P. (2008). Tourisme et développement local [Tourism and Local Development] (p. 192), Belin (in French).

Wendt, J., Buhaș, R., \& Herman, G. V. (2019). Experience of the Baile-Felix Tourist System (Romania) For the Protection and Promotion of the Grey Seal as a Brend on the Hel Peninsular (Poland). Baltic Region/Baltijskij Region, 11(1): 109-116.

*** (2018). World Tourism Organization (WTO), Tourism Highlights

Submitted:

December 27, 2019
Revised:

January 26, 2020
Accepted and published online February 05, 2020 